InOedia $\quad \begin{aligned} & \text { InMedia } \\ & \text { The French Journal of Media Studies }\end{aligned}$

$1 \mid 2012$

Global Film and Television Industries Today

Landscape as the Locus for Artistic Transfers Between Ireland, Northern Ireland and Great Britain (1968 - Present Day)

25 November 2010, Centre Culturel Irlandais, Paris

Charlotte Gould, Caroline Hancock and Sophie Orlando

CpenEdition

Journals

Electronic version

URL: http://journals.openedition.org/inmedia/138

DOI: 10.4000/inmedia.138

ISSN: 2259-4728

Publisher

Center for Research on the English-Speaking World (CREW)

Electronic reference

Charlotte Gould, Caroline Hancock and Sophie Orlando, « Landscape as the Locus for Artistic

Transfers Between Ireland, Northern Ireland and Great Britain (1968 - Present Day) », InMedia [Online],

1 | 2012, Online since 16 March 2012, connection on 08 September 2020. URL : http://

journals.openedition.org/inmedia/138; DOI : https://doi.org/10.4000/inmedia.138

This text was automatically generated on 8 September 2020

(C) InMedia 


\section{Landscape as the Locus for Artistic Transfers Between Ireland, Northern Ireland and Great Britain (1968 - Present Day)}

25 November 2010, Centre Culturel Irlandais, Paris

Charlotte Gould, Caroline Hancock and Sophie Orlando

\section{EDITOR'S NOTE}

Conference organised by PRISMES-Sorbonne Nouvelle - Paris 3-, research group on

British art One Piece at a Time and the Centre Culturel Irlandais

1 This conference was the result of an observation: the violent events that occurred between the end of the 1960s and the Good Friday Agreement in 1998 have often been a focal point in the artistic practices in Ireland, Northern Ireland and Great Britain. The study of Irish art has privileged work based on the political situation in Northern Ireland during and after the Troubles. Recently, the Holden Gallery at Manchester Metropolitan University presented the exhibition Archiving Place and Time: Contemporary Art Practice in Northern Ireland since the Belfast Agreement (2009). ${ }^{1}$ The political and institutional context encouraged the affirmation of specific visual identities. Today, artworks are like imprints of cultural exchanges between these regions and countries. The exhibition "0044," organised by the Crawford Municipal Gallery in Cork in 1999, presented Irish artists living in Great Britain, not only sharing a common national identity, but more importantly experiencing displacement, migration and an encounter with personal and collective history. The Peace Process and the economic development in the region led to great shifts in cultural policies, exhibition venues and artistic practices. The Celtic Tiger, alongside the rise of cheap travel, modified the field of 
possibilities, and the current recession, with the Republic being the hardest hit, will probably bring more transformations.

2 The landscape tradition is a shared subject in British and Irish history of art. Luke Gibbons ${ }^{2}$ establishes a direct link between contemporary art, the terror myth and Edmund Burke's writing about the sublime in the $18^{\text {th }}$ century. As a genre as well as a place, it has come to embody different, and sometimes common, aspects of both British and Irish identities. Willie Doherty represents this relation between landscape, terror and language in a similar vain to British artist Hamish Fulton. Cultural exchanges between artists either side were contested for a long time but nevertheless they existed, being often due to individual efforts such as artists travelling to train in art schools in the UK, and to galleries like the Orchard in Derry or the Kerlin in Belfast and then Dublin. The work of British artist Paul Graham (Troubled Lands, 1987) and of his Irish student Paul Seawright (Sectarian Murders, 1988) are exemplary in their confrontation of documentary and photographic genres in order to deal with political murders and the intrinsic violence in Northern Irish landscapes in the 1970s. Could it be said that landscape is treated somewhat differently in Ireland? This question is often addressed from the angle of the painterly tradition of the 1950s, or associated with the emergence of the feminine in the $20^{\text {th }}$ century. The aim of the conference was to look into possible new definitions of the concept, which might emerge from the observation of the exchanges between three art scenes.

3 Welcoming us at the Centre Culturel Irlandais, director Sheila Pratschke opened the conference, along with the Sorbonne Nouvelle's Vice President, Carle Bonafous-Murat, who insisted on the way the poetical notion that "You say the word, I see the image" subtly introduces the possibility of shifts in perceived rootedness. Sophie Orlando, the founder of One Piece at a Time, introduced the proceedings by setting the notion of landscape, traditional in both British and Irish art, in a contemporary context.

Our first speaker, Maeve Connolly, art critic and senior lecturer at Dun Laoghaire Institute of Art, Design and Technology, presented "On Location: Ireland, Artists' Film and Problems of Representation in Contemporary Art." She examined the significance of location as a point of view which exceeds representation. The past fifteen years have witnessed a renewed interest in the moving image, paralleled by the emergence of new contexts for the production of artists' film and video both inside and outside Ireland, where this period was also marked by unprecedented levels of consumption, fuelled by property speculation and unregulated financial instruments such as derivatives, so complex that they exceed representation. During this same period, cities like Dublin were recast as 'creative capitals,' with the potential to attract desirable and mobile workers. Towards the end of the 1990s, various theorists sought to examine the role of art practice in these reconfigurations of place, labour and value. Some claim that artists exemplify the flexible self-managing worker, producing the self as 'project' while others (like Miwon Kwon, in One Place after Another: Site-Specific Art and Locational Identity) note the rise of site-specific or 'locational' modes of art and curatorial practice, in which artists generate meaning through the ongoing discursive production of space as site. Commissioned artists are often expected to engage with geographical features that are in some sense recognisable. Yet artists working within these contexts are often acutely aware of the complex relationship between site, setting and location within economies of moving image production. In a 1997 October roundtable, George Baker noted that a number of prominent artists working with film originate from, or work in, places that 
have a particular relation to the film industry. For example, Stan Douglas is based in Vancouver, which is popular as a film location because of its capacity to 'stand in' for various other cities. Baker's comments offer a counterpoint to Kwon's critique and another way of conceptualising the relationship between location and site. Connolly illustrated this treatment of location by presenting Leisure Centre, 2005, by Desperate Optimists, itself a commentary on urban regeneration.

5 Gabriel Gee, the treasurer of One Piece at a Time and editor of online journal Pied-àTerre then presented "Le paysage, une identité représentée et réinventée à la Orchard Gallery" ("The Landscape: an Identity Represented and Reinvented by the Orchard Gallery"). Led by Declan McGonagle, the Derry gallery, founded in 1978, emerged and flourished in the very problematic context of the Troubles, which its director wished to confront. McDonagle had insisted on the relevance of inviting English artist Richard Long in 1984 saying that the artists he invited in Derry were not necessarily political artists; Richard Long for example cannot be considered a political artist, but McDonagle invited him because he works with the landscape, and the landscape is a central notion when considering the feelings of identity in Ireland, as well as in Britain. The landscape thus expresses both identity and difference. Something Gee presented in the work of Diarmuid Delargy, Sean Fingleton, Catherine Harper and Patrick Ireland (Brian O'Doherty's name from 72 to 2008). What emerges from the case-study of a NorthernIrish gallery, and which some questions from the audience came to highlight, is the tension between working on a sense of place and parochialism, the negative connotations of the notion of the "local artist."

6 Fionna Barber is Professor of Contextual Studies at Manchester School of Art. She presented "The Specificity of Northern Space: Curating Post-Conflict Art from Northern Ireland" and demonstrated how, since the Good Friday Agreement, much of the work of artists in Northern Ireland has been preoccupied with the transformations that have taken place in a (largely) post-conflict society. A central theme has been the shifting significance of urban space. In Belfast in particular conflict zones have become redefined as tourist destinations, while working-class housing has been replaced by desirable real estate. Yet despite these processes of urban renewal the recent past has proved remarkably resistant to being over-written. In recent photographs by Paul Seawright urban space becomes the site of undisclosed trauma. In these reconfigurations of Northern space the meanings of the rural are also subject to question. Rather than functioning as a site of escape from urban experience, some versions of Northern Irish landscape continue to bear the emotional associations of conflict familiar also from art of the 1980s. She presented the experience of Archiving Place and Time, which, for her, embodied a sense of distance and cultural displacement from the outset; with Barber as originally from Northern Ireland but now living and working in the North of England. She noticed a shift in meanings of these works when exhibited outside Northern Ireland where spectators often begin to engage by situating the works within an awareness of other post-conflict situations on a global scale.

7 Artist Pauline Cummins then looked at the theme of landscape under the headings of sexuality and politics by presenting her own art practice: Inis'Oirr/Aran Dance (a slidesound piece from 1985, an exploration of sexuality and landscape in relation to the patterns of Aran sweaters), Unearthed (1988, a multi-media performance in response to the build-up to Bloody Sunday) and concluded with her most recent work, The Still Centre (2010) that explores landscape through a performative use of video. All these 
works have been shown in Ireland, Northern Ireland, and England, with engagement of audiences in each situation. Cummins insisted on the transfers of the works of art themselves, since some have been shown internationally, allowing for the dispersion of issues.

8 Rachel Brown and Brighdin Farren, who set up Belfast curatorial project Brown\&Bri, presented the new working model they have invented. The way Belfast has developed and now functions is their subject matter. Its artistic community has continuously adapted throughout a conflict which at once depressed and liberated it, providing both enough subject and enough external interest to take its artwork out of Northern Ireland and place it on an international platform. They see shifts and movements in practice being dependent on factors like availability of studio space, funding, representation and market, but also witness the power of art to make visible invisible landscape conditions, to shift things around and remap the city. Relating this to the current situation of large cuts in public funding for the arts, and a need to become more self-reliant, they presented their own practice. They collaborate with other organisations such as the Catalyst Arts Project to curate and deliver projects.

9 In "The Great Hunger: (Re) Visions of Irish Republican Martyrology," Ronnie Close, a senior lecturer at the University of Wales, examined key depictions of Irish Republicanism, presenting two distinct uses of landscape and place: Steve McQueen's film, Hunger (2008) and David Farrell's photographic work, Innocent Landscapes (2001). Close discussed the formalist archaeology of the H.M. Maze Prison as imagined in Hunger, set against what he deemed a far more subtle pictorial romanticism in Innocent Landscapes. Although Farrell's photographic work trades on recognised symbolic notions of the Irish rural idyll, the artist inverts these assumptions. Farrell makes authentic our presence at evidential search procedures by extending the medium outwards as a visual poetic form of witnessing. This is predicated by the absence of bodies, in a sense confounding the documentary tradition. In contrast, Hunger's cinematic vision tends to reaffirm the myth of Irish Republicanism within a heroic framework by focusing on the body trapped in a subterranean landscape of conflict. The popularity of the film has established it as a significant cultural artefact of Republicanism. However this representation is a fictional one, trading on the lack of archival sources and exposing a blind spot in the visual landscape of the Northern Irish conflict. The film is an approximation, dependent on living Republican witnesses. Close finds Hunger perfectly controversial as it uses an uncomplicated template to understand the Hunger Strikers' sacrifice while Innocent Landscapes reveals a dark stain in the landscape: Irish Republicanism.

10 Dublin-based curator Vaari Claffey presented festival-cum-curatorial project Gracelands, which she launched in 2008. The annual open-air art event attracts the Irish art world as much as the local community and introduces a shift towards the countryside. The presentation of past performances and installations provided a lively introduction to the latest developments on the Irish art scene and meant everyone was eager to save the date for the next instalment (September 2011, for more information check: http://www.gracelands.eu/).

11 Renowned Irish artist Anne Tallentire was our last speaker. She uses photography, film and video to chart movement and migrations and the itineraries they inscribe on urban landscapes. As an artist working in Britain, she has experienced first-hand the difficulty for Irish practitioners to be recognised as such abroad. She presented naming, 
translation and work as the three main themes in her work, using The Gap of Two Birds (1989), Nowhere Else and Field Study (both 2010) as examples. Her work was included in a later exhibition at La Galerie Noisy Le Sec (Le Monde Physique, 26 February-23 April 2011).

12 The day ended with "Very Dark Skies Over the Emerald Isle: Events in the Landscape", a screening of a selection of videos compiled by Caroline Hancock which included work by Willie Doherty, Sean Lynch, Rhona Byrne, Bea McMahon, Vivienne Dick, Seamus Harahan, Anne Tallentire, Martin Healy, Jaki Irvine, John Lalor, Grace Weir, Daniel Jewesbury and Mark Garry.

\section{NOTES}

1. Archiving Place and Time. Holden Gallery, Manchester Metropolitan University, November 2009. Organised by Fionna Barber.

2. Luke Gibbons, « L'art et l'inimaginable », in L'Imaginaire irlandais (Paris : Hazan, 1996) 54.

\section{AUTHORS}

\section{CHARLOTTE GOULD}

Université Sorbonne Nouvelle - Paris 3

\section{CAROLINE HANCOCK}

Independent curator and writer

\section{SOPHIE ORLANDO}

Founder and president of the association One Piece at a Time, groupe d'Études Interdisciplinaires sur les Arts Britanniques : http://www.geiab.org/ 